\title{
Pseudostaurosira bardii (Fragilariaceae, Bacillariophyta), a new species from a saline hydrothermal spring of the Massif Central (France)
}

Aude Beauger ${ }^{\mathrm{a}}$, Carlos E. Wetzel ${ }^{\mathrm{b}}$, Olivier Voldoire ${ }^{\mathrm{a}}$ and Luc Ector $^{\mathrm{b}}$

aUniversité Clermont Auvergne, CNRS, GEOLAB, F-63000 Clermont-Ferrand, France; bLuxembourg Institute of Science and Technology (LIST), Department Environmental Research and Innovation (ERIN), 41 rue du Brill, L-4422 Belvaux, Luxembourg

CONTACT Aude Beauger aude.beauger@uca.fr

\section{ABSTRACT}

Light (LM) and scanning electron microscopy (SEM) observations on a new species of the genus Pseudostaurosira from a spring of the Massif Central (France) are presented. The new species with very small dimensions presents similarities with other species previously observed in other parts of Europe. However, based on its morphology, the new species presents striae sometimes composed of only two areolae on the valvar surface: one big, round or elliptic near the mantle edge and the second smaller, slit-like or round (sometimes completely occluded externally) situated further toward the interior. Moreover, the size, the density of striae and the presence of volae allow the separation of Pseudostaurosira bardii from the other species. Morphologically similar species were also reinvestigated in the current project, including the type material of Pseudostaurosira trainorii E. Morales, Pseudostaurosiropsis connecticutensis E. Morales and Pseudostaurosira cataractarum (Hustedt) C.E. Wetzel, E. Morales et Ector. They were also investigated and illustrated using SEM. The ecological preferences of Pseudostaurosira bardii are briefly discussed.

\section{KEYWORDS}

Araphid diatom; epipelon; mineral spring; scanning electron microscopy; type material; ultrastructure 


\section{Introduction}

The taxonomy of genera belonging to the Fragilariaceae have long been problematic despite major taxonomic revisions occurred in the 1980s (Round 1984; Williams 1986; Williams and Round 1987). The genus Fragilaria Lyngbye was originally conceived for species that form linear colonies (Lyngbye 1819). Different taxa were described and associated to Fragilaria as F. pectinalis; this last species has made the lectotype (Tuji and Williams 2006). Later, Ehrenberg (1832) described the genus Synedra using S. ulna (Nitzsch) Ehrenberg as type material. However, the distinction between Synedra and Fragilaria was never clearly defined and many different authors have worked on them (Hustedt 1930, Patrick and Reimer 1966; Lange-Bertalot 1980; Krammer and Lange-Bertalot 1991). Since then, studies have worked out morphological details on many new genera. The subdivision of both Synedra and Fragilaria began with Round (1979, 1984), and later Williams and Round (1987) described a series of new genera as Neofragilaria, Pseudostaurosira, Punctastriata and Staurosirella. The type of Pseudostaurosira is Fragilaria brevistriata Grunow in Van Heurck (Williams and Round 1987; Morales et al. 2015). This genus was described as presenting frustules rectangular, forming chains. For Williams and Round (1987), the valves are elliptical to linear often undulate and occasionally cruciform. As defined by Round, Crawford, and Mann (1990), the striae are uniseriate consisting of a few large elliptical areolae (often smaller round areolae) and rarely more than four areolae per stria. The closing plate is delicate and highly branched and the sternum is wide. Apical pore fields are not always present; if present they usually consist of a few pores. Rimoportulae is absent and mantle plaques are present along the mantle edge. Spathulate or spathulate/branched spines sometimes branched at the tips are situated along the valve edge usually in a somewhat plain region of the valve. The cingulum consists of several open, plain, ligulate copulae and the valvocopula is large and nonareolate. The plastids are probably parietal and plate-like. However, when considering more recent studies, the areolae could be square with rounded corners as for $P$. alvareziae Cejudo-Figueiras, E. Morales et Ector (Cejudo-Figueiras et al. 2011), volae are also observed (Morales 2005; CejudoFigueiras et al. 2011) as in $P$. alvareziae and $P$. subsalina. More than four areolae were observed on the valve face for $P$. trainorii (number of areolae between 1 and 6) (Morales 2001). Another interesting feature observed was the presence of quasifract bands (presenting a general appearance of being broken in small units), a character also observed in Pseudostaurosira cataractarum and $P$. (Nanofrustulum) shiloi (Round, Hallsteinsen, and Paasche 1999) and also found in members of the Cymatosiraceae family (Hasle, Stosch Von, and Syvertsen 1983).

To date, the genus Pseudostaurosira currently holds 35 species and 8 varieties (Fourtanier and Kociolek 2011; Kulikovskiy, Genkal, and Mikheyeva 2011; Wetzel et al. 2013; Morales et al. 2015; Guiry and Guiry 2017). Most species are from freshwater environments although some of them are brackish species, such as the recently described by Seddon and Witkowski Pseudostaurosira diablarum observed in a mangrove ecosystem in the Galápagos Islands (Seddon et al. 2014).

A new Pseudostaurosira was observed in a mineral spring found in the French Massif Central, more precisely in the Puy-de-Dôme department. Truchot (1878) described more than 200 springs linked to the geology and past volcanic activities. Due to the history of the massif (over $85,000 \mathrm{~km}^{2}$ ), a high variety of habitat conditions is present with high altitude springs (>1000 $\mathrm{m}$ a.s.l.), salt spring and also the hottest spring of Europe $\left(80^{\circ} \mathrm{C}\right)$. The first studies conducted on springs from the Massif Central underlined the high algae biodiversity (Héribaud 1893; Chaouite 1987; Chaouite and Romagoux 1989; Tudesque 1996; Cordonnier 2008). The first survey performed in 2014-2015 in order to estimate the biodiversity in different mineral springs more or less impacted by human activities, revealed the presence of several new taxa, including some recently described such as Navicula sanctamargaritae Beauger in Beauger et al. (2015) and Sellaphora labernardierei Beauger, C.E. Wetzel et Ector in Beauger et al. (2016). In the present paper a new species of Pseudostaurosira is described using light (LM) and scanning electron microscopy (SEM). A morphological comparison is made with the most similar Pseudostaurosira taxa and its ecology is also addressed. Moreover, the type material of similar small elliptic araphid species: P. trainorii E. Morales (Avery Pond, Connecticut USA), Pseudostaurosiropsis connecticutensis E. Morales (Avery Pond, Connecticut USA) and Pseudostaurosira cataractarum (Hustedt) C.E. Wetzel, E. Morales et Ector (Java, Indonesia) were obtained, investigated and illustrated by SEM in this article. Pseudostaurosira cataractarum observed in the French Massif Central was also investigated and illustrated by SEM. 


\section{Materials and Methods}

Study site. The Cézallier area belongs to an active natural hydrothermal system located in the northern section of the French Massif Central (Figure 1). The Cézallier area basement is primarily composed of Variscan metamorphic rocks, which are partially covered by bedrock or else a Quaternary alkaline basalt (Feuga 1987). In the Cézallier region, located south of Clermont-Ferrand, some fifty cold mineral springs have been identified over the last 15 years (Fouillac 1983). These springs are saline and carbo-gaseous hydrothermal waters. The waters are neutral ( $\mathrm{pH} 6-7)$ and not in equilibrium with atmospheric $\mathrm{CO}_{2}$ pressure (Cornu, Négrel, and Brach 2001). Their chemical composition is dominated by $\mathrm{Cl}, \mathrm{Na}$ and $\mathrm{HCO}_{3}$, and they are commonly rich in calcium, iron, aluminium, phosphate and in trace elements (arsenic, selenium, etc.) (Fouillac 1983; Beaucaire, Criaud, and Michard 1987; Criaud and Fouillac 1989; Négrel et al. 2000). According to Criaud and Fouillac (1989) and Négrel et al. (2000), these waters are derived from the mixing of meteoric water with deep water during their convective cycle and final rise through the fractured Hercynian metamorphic basement. Arriving at the surface, CO degassing and changes in the oxidation state of these waters give rise to the formation of carbonates and iron oxides that trap a certain number of trace elements (Beaucaire, Criaud, and Michard 1987). The spring outlets are, thus, commonly associated with travertine extending over a surface of one to several meters in length (Cornu, Négrel, and Brach 2001). The present study focuses on an area comprising several spring outlets located nearby the hamlet of Bard (Boudes, Puy-de-Dôme department, Auvergne-Rhône-Alpes region). The springs (included the studied ones: Bard and Bard 2) lie along a fault and rise through heterogeneous anatexite (Berthier et al. 1982). Bard spring is characterized by the presence of a small roman basin in stone and is situated next to pastures (elevation of $489 \mathrm{~m}$ a.s.I.) while Bard 2 spring is located within an oak grove (elevation of $496 \mathrm{~m}$ a.s.l.). The new Pseudostaurosira species was observed only in Bard 2.

Diatom sampling and chemical analyses. An epipelic sample coming from the Bard 2 spring was taken by picking up sediment (mainly silt) in the basin on 11 December 2015. The geographical position of the sampling site was taken using a DGPS Trimble Geo7x, in Lambert 93. Conductivity $\left(\mu \mathrm{S} . \mathrm{cm}^{-1}\right), \mathrm{pH}\left(\mathrm{pH}\right.$ units), and water temperature $\left({ }^{\circ} \mathrm{C}\right)$ were measured at the sampling site, using a WTW Multiline P4. The oxygen was measured using an oximeter Ysi ProODO A water sample was collected for further chemical analysis in the laboratory and was analysed using the high pressure ion chromatography technic. First, these samples were filtered using Whatmann GF/C filters. For the cation analysis, a Thermo Scientific Dionex ICS1100 system was used; and for the anions, a Thermo Scientific Dionex DX120 system. The concentrations ( $\left.\mathrm{mg} \mathrm{L}^{-1}\right)$ of lithium, sodium, ammonium, potassium, magnesium, calcium, fluoride, chloride, nitrite, nitrate, phosphate, sulphate and carbonate were measured in the laboratory.

Type material. We obtained the type material of the three more similar taxa to the new species belonging the genus Pseudostaurosira. For P. trainorii E.Morales (2001) and Pseudostaurosiropsis connecticutensis E.Morales (2001), we worked on the material \#4198 of the General Collection, Diatom Herbarium, Academy of Natural Sciences of Philadelphia collected from the Avery Pond, Connecticut (U.S.A). For Pseudostaurosira cataractarum (Hustedt) C.E.Wetzel, E. Morales et Ector in Wetzel et al. (2013), we used the type material AS1524 from the Hustedt Collection (Alfred-WegenerInstitut für Polar- und Meeresforshung, Bremerhaven, Germany) collected from Tjurug Tjibeureum waterfalls, Java (Indonesia). The material corresponds to the holotype slide no. A2/27.

Diatom analyses. Small sub-samples of raw material were prepared for LM observation following the method described in Prygiel and Coste (2000). Samples were cleaned using hydrogen peroxide $\left(\mathrm{H}_{2} \mathrm{O}_{2}\right.$, $35 \%)$ and hydrochloric acid $(\mathrm{HCl})$, and rinsed several times. Cleaned material was diluted with distilled water to avoid excessive concentrations of diatom valves on the slides and mounted in Naphrax®. LM observations were done using a Leica ${ }^{\circledR}$ DM2700M microscope with 100x oil immersion objective using a differential interference contrast. Morphometric measurements were performed using a Leica ${ }^{\circledR}$ DMRX bright field microscope with 100x oil immersion objective, and light photographs were taken with a Leica ${ }^{\circledR}$ DC500 camera. For the scanning electron microscopy (SEM), parts of the oxidized suspensions were filtered with additional deionized water through a 3- $\mu \mathrm{m}$ Isopore ${ }^{\mathrm{TM}}$ polycarbonate membrane filter (Merck Millipore). Filters were mounted on aluminium stubs and coated with platinum using a Modular High Vacuum Coating System BAL-TEC MED 020 (BAL-TEC AG, Balzers, Liechtenstein). An ultrahigh-resolution analytical field emission (FE) scanning electron microscope Hitachi SU-70 (Hitachi High-Technologies Corporation, Japan) operated at $5 \mathrm{kV}$ and $10 \mathrm{~mm}$ distance 
was used for the analysis. SEM images were taken using the lower (SE-L) and upper (SE-U) detector signal and sometimes tilted up to an angle of 28 degrees. Photographs were digitally manipulated and plates containing light and scanning electron microscopy images were created using CorelDraw X6. Samples and slides are stored at the Herbiers Universitaires de Clermont-Ferrand, France (CLF) and Botanic Garden Meise, Belgium (BR).

Morphological terminology follows Ross et al. (1979) (striae, areolae and spines), Barber and Haworth (1981) (valve shape and striae orientation) and Round, Crawford, and Mann (1990) (areolar substructures, girdle band features and apical pore field characteristics). To compare the new species with the other small-celled fragilarioids retained we used the previous taxonomic literature (Ross et al. 1979; Barber and Haworth 1981; Round, Crawford, and Mann 1990) and Hasle, von Stosch, and Syvertsen (1983).

\section{Results}

Pseudostaurosira bardii Beauger, C.E. Wetzel et Ector, sp. nov. (Figures 2-56)

Description: LM: Frustules rectangular in girdle view, forming chains with the aid of spines (Figures 43-46, 51-53). Valves isopolar, elliptical to round with broadly rounded ends; 4.0-6.5 $\mu \mathrm{m}$ long, 3.0$5.5 \mu \mathrm{m}$ wide $(\mathrm{n}=50)$. Sternum generally wide. Striae alternate, parallel or slightly radial towards the apices (Figures 2-42, 47-50); stria density 12-16 in $10 \mu \mathrm{m}$. Plastids not observed.

SEM: Siliceous plaques present along valve mantle edge (Figures 51-54). Striae uniseriate, composed of mainly 1-2 areolae and sometimes 3 areolae on valve face and 1-2 areolae on valve mantle (Figures 47-50, 54-56). Striae distinct, composed of round to elliptical (transapically elongated) areolae decreasing in size from the valve face/mantle edge to both the central sternum and the valve mantle (Figures 47-50). Striae sometimes composed of only two areolae: one round and the second long and elliptical (Figure 47).Volae generally robust and arising from the inner periphery of each areola (Figure 56). Spines variable in shape, from spatulate (Figure 51) to lanceolate (Figure 53), always with serrate margins near the apices (Figures 51-53), interrupting the striae at the valve face/mantle junction (Figures 47-50). Costae slightly raised with respect to striae (Figures 48, 54). Apical pore fields absent or very weakly developed, composed of few round poroids (Figure 55 partially occluded). Valves present 'discrete' apical pore fields mainly detected internally (Figure 56). Rimoportula absent. Copulae and girdle bands are open, segmented (quasifract) and not perforated (Figure 54).

Holotype: Holotype population deposited in Herbiers Universitaires de Clermont-Ferrand, France (CLF 104885).

Isotype: Populations deposited in Herbiers Universitaires de Clermont-Ferrand, France (CLF 104886) and in Botanic Garden Meise, Belgium (BR-4469).

Type locality: Bard 2 spring at Boudes (Puy-de-Dôme department, Auvergne-Rhône-Alpes region, France), E713631.82 and N6483209.55.

Etymology: The term "bardii" refers to the Bard spring in the Massif Central.

Associated diatom species: Among the benthic species found in the holotype slide, the dominant taxa were Crenotia thermalis (Rabenhorst) Wojtal (50\%), Navicula sanctamargaritae (12\%) and Planothidium frequentissimum (Lange-Bertalot) Lange-Bertalot (10\%). The other associated taxa $(<5 \%)$ were Diploneis krammeri Lange-Bertalot et E.Reichardt, D. fontium E. Reichardt et LangeBertalot, Fallacia pygmaea (Kützing) Stickle et D.G. Mann, Navicula veneta Kützing, Nitzschia supralitorea Lange-Bertalot, Rhopalodia acuminata Krammer, Sellaphora atomoides C.E.Wetzel et Van de Vijver, Sellaphora nigri (De Notaris in De Notaris \& Baglietto) C.E.Wetzel et Ector.

Physical and chemical character of the spring water: The spring has a slightly acidic $\mathrm{pH}$ (6.53), an elevated conductivity level $\left(6510 \mu \mathrm{S} \mathrm{cm}^{-1}\right)$ and is enriched with sodium-chloride and bicarbonate (Table 1). The concentrations of the different ions (potassium, calcium and magnesium) are also 
elevated $\left(>100 \mathrm{mg} \mathrm{L}^{-1}\right)$. The water temperature is about $15^{\circ} \mathrm{C}$ throughout the year. The concentration of lithium ions $\left(4.8 \mathrm{mg} \mathrm{L}^{-1}\right)$ denote the deep water origin (Michard 1990).

\section{Additional type materials investigated}

In order to compare the new species Pseudostaurosira bardii, three similar species were examined (Figures 87-94; Table 2) and their type materials were examined. The original descriptions (valve dimensions and number of striae) are summarized in Table 2 . The species are already well illustrated in LM in previous publications (Morales 2001; Wetzel et al. 2013). However, LM pictures of $P$.

cataractarum were presented because living populations were observed for the first time in the mineral springs from France and Europe.

Pseudostaurosira trainorii E.Morales (2001, p. 113, fig. 6a-l)

Figures 87-90 (SEM)

Holotype: Material \#4198.

Type locality: Avery Pond, Connecticut, U.S.A.

Description: Valves elliptical to round. Number of striae only very rarely as low as 15 or as high as 30 per $10 \mu \mathrm{m}$. Number of areolae on valve face varies between 1 and 5 , whereas at the valve mantle this number ranges from 2 to 4 (Figure 87). Sternum generally wide, although in the morphs possessing a high number of areolae on the valve face, the sternum can be substantially reduced in width (Figures 88,89 ). Apical pore fields generally absent, but sometimes reduced pore fields composed of 2 or 3 poroids are present on the valve mantle (Figure 87).

Ecology: Found in lentic ecosystems (Morales 2001; Morales et al. 2010) and large rivers as the Loire River (Ector et al. 2015).

Pseudostaurosiropsis connecticutensis E.Morales (2001, p. 117, fig. 7a-I)

Figures 91, 92 (SEM)

Holotype: Material \# 4198.

Type locality: Avery Pond, Connecticut, U.S.A.

Description: Valves round to narrowly elliptical in shape. Number of areolae per stria varies between 2 and 6 and number of areolae on either valve face or valve mantle between 1 and 3 . Apical pore fields generally absent, but sometimes reduced pore fields composed of 2 or 3 poroids are present on the valve mantle (Figure 91). The girdle bands seem to be open and not segmented.

Ecology: Found in small, mesotrophic to eutrophic, shallow lakes.

Pseudostaurosira cataractarum (Hustedt) C.E. Wetzel, E. Morales et Ector in Wetzel et al. (2013, p. 56 , figs $1 A-A B, 2 A-G)$

Figures 93, 94 (SEM)

Type material: Material AS1524.

Type locality: Tjibeureum Wasserfall, Java TJ2.III.c. 
Description: Valves are round to slightly elliptical. Striae radiate throughout the entire valve and extending onto the valve mantle. The striae are composed of round to oval areolae with the oval areola at the center; the number varies between 1 and 5 areolae per stria. The girdle bands are open, segmented (quasifract) and not perforated.

Ecology: Found in different countries and ecosystems such as hot springs (Wetzel et al. 2013). At the Massif Central, this taxa was observed in two different mineral springs: Puits spring at Courpière $(E$ 706546.54 and N 6475917.38and Zagat spring at Ardes-sur-Couze (E 744209.91 and N 6516138.53 (Figures 57-86). The dimensions were those reported by Grana et al. (2015). In the Massif Central, the springs were temperate and a difference of mineralization was observed between the two sites (Table 2).

\section{Discussion}

Pseudostaurosira bardii belongs the genus defined by Williams and Round (1987). The taxa currently ascribed to this genus share many features that were observed on the type $P$. brevistriata, such as the type of striae and areolae (short striae and wide areolae bearing well-developed volae), the position of the spines (interrupting the striae) and the characteristics of the apical pore fields (Williams and Round 1987; Morales et al. 2015). In LM, the areolae could be resolvable (Fig. 12) but sometimes the observation is difficult and, thus, the new taxon could not be confused with other taxa such as Staurosira venter (Ehrenberg) Cleve et J.D.Möller), Staurosirella ovata E.Morales et Manoylov or Punctastriata ovalis D.M. Williams et Round (Williams and Round 1987; Morales and Manoylov 2006).

An extensive literature search was conducted and revealed some taxa that appear morphologically similar under the LM to Pseudostaurosira bardii and could therefore be confused with this new species. Three species were retained based on their LM morphology (Table 3). We eliminated after comparison and literature analysis, $P$. shiloi (J.J. Lee, Reimer et McEnery) Hallegraeff et Burford as it is smaller (2.8-7.5 $\mu \mathrm{m}$ long) and has a lower number of striae (10-12 per $10 \mu \mathrm{m})$ than $P$. bardii, the narrow $P$. sajamaensis E. Morales et Ector in Morales et al. (2012) (2-4 $\mu \mathrm{m}$ wide) has only 1 or 2 areolae round or trapezoid per striae. We also eliminated $P$. sopotensis (Witkowski et Lange-Bertalot) E.Morales, C.E.Wetzel et Ector in Wetzel et al. (2013) even if this taxon inhabits brackish waters, because the valve face striae are composed of very fine poroids (ca. 40 in $10 \mu \mathrm{m}$ ) prolonged by several (up to 4) larger areolae on the mantle avoiding confusion with the new taxon $P$. bardii. At last, Staurosira altiplanensis Lange-Bertalot and Rumrich in Rumrich et al. (2000), is more elliptical and narrower (2.8-3.6 $\mu \mathrm{m}$ wide) than the new species as was not retained.

Actually, the areolae were never observed as transapically elongated with no more than two areolae. Based on LM and SEM morphology, the new species presents particular features that have not been described previously in the genus such as the special pattern of the areolae: the striae are composed of mainly 1-2 areolae and sometimes 3 areolae on valve face and 1-2 areolae on valve mantle, that are round to elliptical (transapically elongated); the areolae decrease in size from the valve face/mantle edge to both the central sternum and the valve mantle. Sometimes the striae are composed of only two areolae (one round and the second long and elliptical) and the presence of the slit like areolae could be related to the cell life cycle. Even if the last characteristic is common to taxa such as Pseudostaurosira alvareziae, P. americana and P. subsalina (Cejudo-Figueiras et al. 2011), the association of all the characteristics: the size, the areola pattern, the density of striae and the presence of volae allow to separate $P$. bardii from the other described species of the genus.

Confusion in LM could occur with $P$. trainorii, but this species has a higher number of areolae per stria (up to six) than $P$. bardii (Morales 2001). In SEM, even if similarities occur between both species such as the presence of serrate spines, differences allow to separate them. The first difference is the pattern of striae: they consisted of rows of circular to elliptical areolae, which are occluded with complex vela and extended from the valve face onto the mantle (Morales 2001; Morales et al. 2010; Sato et al. 2011). Moreover, P. trainorii is mainly observed in lentic habitat with low conductivity (ca. $125 \mu \mathrm{S} \mathrm{cm}{ }^{-1}$ ). For Pseudostaurosiropsis connecticutensis, only the smaller representatives have similarities with the new species; $P$. connecticutensis, a freshwater species, has a higher stria density (17-20 per $10 \mu \mathrm{m})$ and, observed using SEM, the closing plate consists of a disk-like structure that covers most of the areolar opening, a characteristic typical of the genus Pseudostaurosiropsis (Morales 2001) (Figure 91). In Pseudostaurosira species, even if this kind of 
flaps could be observed, underneath them there are developed volae as in $P$. bardii. When considering $P$. cataractarum, confusion could occur with $P$. bardii based on the areola pattern and the presence in springs (Wetzel et al. 2013), even if the striae appear to be thinner and the valve shape more rounded in LM (Figures 59-77) for $P$. cataractarum. Indeed, the oval and long areola near the sternum is similar in both species when this kind of areola is present for the new species. However, $P$. cataractarum is larger $(5.8-8.2 \mu \mathrm{m})$ than the new species, the apical pore fields are absent and vola are not present. Moreover, for this species the number of areolae on the valve mantle is high (2 to 5 ) (Figures $78,79,84,86,94$ ) instead of one large areola and sometimes a second smaller for $P$. bardii. When we compared the two species that were observed in Massif Central $(P$. bardii from Bard spring and $P$. cataractarum from Puits and Zagat springs), the differences in LM and SEM are clear.

\section{ACKNOWLEDGEMENTS}

Funding for this research was partly provided in the framework of the project DIATOMS (LIST Luxembourg Institute of Science and Technology) and by the project OBLA (Réseau d'Observation de la Biodiversité de la Loire et de ses Affluents) of the ZAL (Zone Atelier Loire). We thank Dr. Peter Siver for sending us the material from Connecticut, U.S.A and Prof. Karen K. Serieyssol for her precious English corrections. Two anonymous reviewers are thanked for their valuable comments.

\section{Disclosure statement}

No potential conflict of interest was reported by the authors.

\section{Notes on contributors}

Aude Beauger is an ecologist and $\mathrm{PhD}$ at the Centre national de la recherche scientifique. She has written over 20 articles and he has been working on diatoms in rivers, lakes and springs. She has been teaching on bioassessment using diatoms. She is the treasurer of the "Association des Diatomistes de Langue Française (ADLaF)" and have organized the annual meeting on diatom taxonomy, ecology and related subjects in 2014. Contribution: create the research program "Biodiversity study of the diatoms of mineral springs of the French Massif Central" and write the article.

Carlos Wetzel is a botanist and a researcher at the Luxembourg Institute of Science and Technology. He has written over 90 articles and he has been working on diatoms in rivers, lakes and soils. Carlos Wetzel has been teaching numerous training courses on diatom ecology and taxonomy designed for biologists, technicians and ecologists, contributing to the continuous improvement in the Water Framework Directive implementation in Europe. Contribution: plates, discussion of results and development of manuscript.

Olivier Voldoire is engineer assistant at the CNRS. He has participated in more than 20 articles. He is specialized in scientific instrumentation and particularly in physical and chemical analyses. He participate in the research program "Biodiversity study of the diatoms of mineral springs of the French Massif Central". Contribution: write of the Tables 1 and 2 and discussion of the physical and chemical results.

Luc Ector is a botanist and senior researcher at the Luxembourg Institute of Science and Technology. He has written over 185 articles and has been working on diatoms in rivers, lakes and soils for the last 30 years. He was the President of the "Association des Diatomistes de Langue Française (ADLaF)", which organizes annual meetings on diatom taxonomy, ecology and related subjects. Over the last 20 years, he has been organizing and teaching numerous training courses on diatom ecology and taxonomy designed for biologists, technicians and ecologists, contributing to the continuous 
improvement in the Water Framework Directive implementation in Europe. Contribution: discussion of results and development of manuscript.

\section{References}

Barber, H. G., and E. Y. Haworth, 1981. "A guide to the morphology of the diatom frustule with a key to the British freshwater genera." Freshwater Biological Association Scientific Publication 44: 1-112.

Beaucaire, C., A. Criaud, and G. Michard. 1987. "Contrôle des concentrations de certains éléments trace (As, Sb, Ge, U, Ra, Ba) dans les eaux du Cézallier (Massif Central, France)." [Controlling the concentrations of certain trace elements (As, Sb, Ge, U, Ra, Ba) in the waters of Cézallier (Massif Central, France)]. Chemical Geology 63 (1-2): 85-99. doi: 10.1016/0009-2541(87)90076-3

Beauger, A., O. Voldoire, A. Mertens, R. Le Cohu, and B. Van de Vijver. 2015. "Two new Navicula species (Bacillariophyceae) from Western Europe." Phytotaxa 230 (2): 172-182. doi:

10.11646/phytotaxa.230.2.4

Beauger, A., C. E. Wetzel, O. Voldoire, A. Garreau, and L. Ector. 2016. "Sellaphora labernardierei (Sellaphoraceae, Bacillariophyta), a new epilithic species from French spring and four new combinations within the genus Sellaphora." Phytotaxa 260 (3): 235-246. doi:

10.11646/phytotaxa.260.3.3

Berthier, F., J. Demange, C. Fouillac, and F. lundt.1982. Reconnaissance géothermique haute énergie dans la région de Saint-Flour (Massif Central) [High energy geothermal reconnaissance in the region of Saint-Flour (Massif Central)]. Report of B.R.G.M. 82 SGN 723 GHT, 47 pp. Orléans: Bureau de Recherches Géologiques et Minières, Service Géologique National, Département géothermie.

Cejudo-Figueiras, C., E. A. Morales, C. E. Wetzel, S. Blanco, L. Hoffmann, and L. Ector. 2011. "Analysis of the type of Fragilaria construens var. subsalina (Bacillariophyceae) and description of two morphologically related taxa from Europe and the United States." Phycologia 50 (1): 67-77. doi: $10.2216 / 09-40.1$

Chaouite, J. 1987. "Contribution à l'étude des protistes des eaux minérales et thermo-minérales en Auvergne." [Contribution to the study of protists of mineral and thermo-mineral waters in Auvergne]. PhD diss., Université Blaise Pascal, Clermont-Ferrand.

Chaouite, J., and J.-C. Romagoux. 1989. "La flore diatomique des eaux minérales de Vichy (Allier) et de Chaudes-Aigues (Cantal)." [The diatom flora of the mineral waters of Vichy (Allier) and ChaudesAigues (Cantal)]. Revue des Sciences Naturelles d'Auvergne 55: 7-23.

Cordonnier, S. 2008. "Les sources salées d'Auvergne." [The salt springs of Auvergne]. Le Courrier de la Nature 237: 34-41.

Cornu, S., P. Négrel, and M. Brach. 2001. "Impact of carbo-gaseous saline waters registered by soils." Catena 45 (3): 209-228. doi: 10.1016/S0341-8162(01)00147-3

Criaud, A., and C. Fouillac. 1989. "The distribution of arsenic (III) and arsenic (V) in geothermal waters: Examples from the Massif Central of France, the Island of Dominica in the Leeward Islands of the Caribbean, the Valles Caldera of New Mexico, U.S.A., and southwest Bulgaria." Chemical Geology 76 (3-4): 259-269. doi: 10.1016/0009-2541(89)90095-8

Ector, L., C. E. Wetzel, M. H. Novais, and D. Guillard. 2015. Atlas des diatomées des rivières des Pays de la Loire et de la Bretagne. [Atlas of the diatoms of the rivers of Pays de la Loire and Bretagne]. Nantes: DREAL Pays de la Loire. Available online at http://www.pays-de-laloire.developpement-durable.gouv.fr/atlas-des-diatomees-des-rivieres-des-pays-de-la-a3482.html 
Ehrenberg, C. G. 1832. "Über die Entwickelung und Lebensdauer der Infusions thiere; nebst ferneren Beiträgen zu einer Vergleichung ihrer organischen Systeme." [On the development and life of the infusion animals; together with further contributions to a comparison of their organic systems]. Abhandlungen der Königlichen Akademie der Wissenschaften zu Berlin 1831: 1-154, 4 pls.

Feuga, B. 1987. "Le système géothermal du Cézallier: cadre géologique général et reconnaissance par sondages." [The geothermal system of Cézallier: general geological framework and reconnaissance by drillings] Géologie de la France 4: 3-16.

Fouillac, C. 1983. "Chemical geothermometry in $\mathrm{CO}_{2}$-rich thermal waters. Example of the French Massif Central." Geothermics 12 (2-3): 149-160. doi: 10.1016/0375-6505(83)90025-1

Fourtanier, E., and J. P. Kociolek. 2011. Catalogue of Diatom Names, California Academy of Sciences. On-line Version updated 19 Sep 2011. Available online at http://researcharchive.calacademy.org/research/diatoms/names/index.asp

Grana, L., E. A. Morales, T. Bešta, D. Echazú, C. E. Wetzel, M. H. Novais, H. Rajdlová, L. Ector, and N. I. Maidana. 2015. "On the geographical distribution and ecology of Pseudostaurosira cataractarum (Bacillariophyceae): new findings in the Palearctic and Neotropic ecozones." Brazilian Journal of Botany 38 (4): 809-821. doi: 10.1007/s40415-015-0188-0

Guiry, M. D., and G. M. Guiry. 2017. AlgaeBase. World-wide electronic publication, National University of Ireland, Galway. Accessed 09 January 2017. Available online at http://www.algaebase.org

Hasle, G. R., H. A. von Stosch, and E. E. Syvertsen. 1983. "Cymatosiraceae, a new diatom family." Bacillaria 6: 9-156.

Héribaud, J. 1893. Les diatomées d'Auvergne [The diatoms of Auvergne]. Clermont-Ferrand: Pensionnat des Frères des Écoles Chrétiennes - Paris: Librairie des Sciences Naturelles Paul Klincksieck.

Hustedt, F. 1930. Bacillariophyta (Diatomeae). In: Die Süsswasser-Flora Mitteleuropas. Heft 10, edited by A. Pascher, 466 pp. Jena: Gustav Fischer.

Hustedt, F. 1932. Die Kieselalgen Deutschlands, Österreichs und der Schweiz unter Berücksichtigung der übrigen Länder Europas sowie der angrenzenden Meeresgebiete. [The diatoms of Germany, Austria and Switzerland taking into account the other European countries and the adjacent marine areas.] In Kryptogamen Flora von Deutschland, Österreich und der Schweiz 7/2, edited by L. Rabenhorst. Leipzig: Akademische Verlagsgesellschaft m.b.h.

Krammer, K., and H. Lange-Bertalot. 1991. Bacillariophyceae 3. Teil: Centrales, Fragilariaceae, Eunotiaceae. In Süsswasserflora von Mitteleuropa 2/3, edited by H. Ettl, J. Gerloff, H. Heynig, and D. Mollenhauer, 576 pp. Stuttgart, Jena: Gustav Fischer Verlag.

Kulikovskiy, M. S., S. I. Genkal, and T. M. Mikheyeva. 2011. "New data on the Bacillariophyta of Belarussia. 2. Fam. Fragilariaceae (Kütz.) De Tony, Diatomaceae Dumort. and Tabellariaceae F. Schütt." Algologia 21 (3): 357-373, 13 pls (in Russian).

Lange-Bertalot, H. 1980. "Zur systematischen Bewertung der bandförmigen Kolonien bei Navicula und Fragilaria. Kriterien für die Vereinigung von Synedra (subgen. Synedra) Ehrenberg mit Fragilaria Lyngbye." [For the systematic evaluation of the band-shaped colonies in Navicula and Fragilaria. Criteria for the union of Synedra (subgene Synedra) Ehrenberg with Fragilaria Lyngbye]. Nova Hedwigia 33: 723-787.

Lyngbye, H. C.1819. Tentamen hydrophytologiae danicae continens omnia hydrophyta cryptogama Daniae, Holsatiae, Faeroae, Islandiae, Groenlandiae hucusque cognita, systematice disposita, descripta et iconibus illustrata, adjectis simul speciebus norvegicis. [An Danish hydrophytological 
study that holds together all hydrophytes Cryptogama of Denmark, Holstein, Faeroes, Iceland, Groenlandiae hitherto unknown to me, systematically arranged, as described and illustrated by icons, by adding at the same time the species of Norway]. Hafniae [Copenhagen]: Librariae Gyldendaliae.

Michard, G. 1990. "Behaviour of major elements and some trace elements ( $\mathrm{Li}, \mathrm{Rb}, \mathrm{Cs}, \mathrm{Sr}, \mathrm{Fe}, \mathrm{Mn}, \mathrm{W}$, F) in deep hot waters from granitic areas." Chemical Geology 89 (1-2): 117-134. doi: 10.1016/00092541(90)90062-C

Morales, E. A. 2001. "Morphological studies in selected fragilarioid diatoms (Bacillariophyceae) from Connecticut waters (U.S.A.)." Proceedings of the Academy of Natural Sciences of Philadelphia 151: 105-120.

Morales, E. A. 2005. "Observations of the morphology of some known and new fragilarioid diatoms (Bacillariophyceae) from rivers in the USA." Phycological Research 53 (2): 113-133. doi: 10.1111/j.1440-183.2005.00378.x

Morales, E. A., and K. M. Manoylov. 2006. "Morphological studies on selected taxa in the genus Staurosirella Williams et Round (Bacillariophyceae) from rivers in North America." Diatom Research 21 (2): 343-364. doi: 10.1080/0269249X.2006.9705674

Morales, E. A., M. B. Edlund, and S. A. Spaulding. 2010. "Description and ultrastructure of araphid diatom species (Bacillariophyceae) morphologically similar to Pseudostaurosira elliptica (Schumann) Edlund et al." Phycological Research 58: 97-107. doi: 10.1111/j.1440-1835.2010.00567.x

Morales, E. A., C. E. Wetzel, B. Van de Vijver, and L. Ector. 2015. "Morphological studies on type material of widely cited araphid diatoms (Bacillariophyta)." Phycologia 54 (5): 455-470. doi: $10.2216 / 15-21.1$

Négrel, Ph., C. Guerrot, A. Cocherie, M. Azaroual, M. Brach, and Ch. Fouillac. 2000. "Rare earth elements, neodymium and strontium isotopic systematics in mineral waters: evidence from the Massif Central, France." Applied Geochemistry 15 (9): 1345-1367. doi: 10.1016/S0022-1694(97)00094-2

Patrick, R., and C. W. Reimer. 1966. "The diatoms of the United States. Exclusive of Alaska and Hawaii. Volume 1. Fragilariaceae, Eunotiaceae, Achnanthaceae, Naviculaceae." Monographs of the Academy of Natural Sciences of Philadelphia 13: 1-688.

Prygiel, J., and M. Coste. 2000. Guide méthodologique pour la mise en œuvre de l'Indice Biologique Diatomées NF T 90-354. [Methodological guide for the implementation of the Diatom Biological Index NF T 90-354]. Paris: Agences de l'Eau - Ministère de l'Aménagement du Territoire et de l'Environnement Direction de l'Eau - Cestas: Cemagref.

Ross, R., E. J. Cox, N. I. Karayeva, D. G. Mann, T. B. B. Paddock, R. Simonsen, and P. A. Sims. 1979. "An amended terminology for the siliceous components of the diatom cell." Beihefte zur Nova Hedwigia 64: 513-533.

Round, F. E. 1979. "The classification of the genus Synedra." Beihefte zur Nova Hedwigia 64: 135146.

Round, F. E. 1984. "The circumscription of Synedra and Fragilaria and their subgroupings." In Proceedings of the Seventh International Diatom Symposium. Philadelphia, August 22-27, 1982, edited by D. G. Mann, 241-253. Koenigstein: Otto Koeltz.

Round, F. E., R. M. Crawford, and D. G. Mann. 1990. The diatoms: biology \& morphology of the genera. Cambridge: Cambridge University Press. 
Round, F. E., H. Hallsteinsen, and E. Paasche. 1999. "On a previously controversial "fragilarioid" diatom now placed in a new genus Nanofrustulum." Diatom Research 14 (2): 343-356. doi: 10.1080/0269249X.1999.9705476

Sato, S., G. Beakes, M. Idei, T. Nagumo, and D. G. Mann. 2011. "Novel sex cells and evidence for sex pheromones in diatoms." PLoS ONE 6 (10): e26923. doi: 10.1371/journal.pone.0026923

Seddon, A. W. R., A. Witkowski, C. A. Froyd, K. J. Kurzdłowski, J. Grzonka, and K. J. Willis. 2014. "Diatoms from isolated islands II: Pseudostaurosira diablarum, a new species from a mangrove ecosystem in the Galápagos Islands." Diatom Research 29 (2): 201-211. doi: 10.1080/0269249X.2013.877084

Truchot, P. 1878. Dictionnaire des eaux minérales du département du Puy-de-Dôme [Dictionary of mineral waters of the department of Puy-de-Dôme]. Paris: A. Delahaye, Libraire-Éditeur.

Tudesque, L. 1996. "Étude hydrobiologique de trois sites halophiles: Bard, Saint Nectaire, Les Saladis." [Hydrobiological study of three halophilic sites: Bard, Saint Nectaire, Les Saladis]. Mémoire de Diplôme Universitaire Supérieur (mention Hydrobiologie), Université Blaise Pascal, ClermontFerrand et Centre National de la Recherche Scientifique. Géodynamique des Milieux Naturels et Anthropisés. URA 1562- CNRS. Conservatoire des Espaces et Paysages d'Auvergne.

Tuji, A., and D. M. Williams. 2006. "Typification of Conferva pectinalis O. F. Müll. (Bacillariophyceae) and the identity of the type of an alleged synonym, Fragilaria capucina Desm." Taxon 55 (1): 193-199. doi: $10.2307 / 25065541$

Wetzel, C. E., E. A. Morales, S. Blanco, and L. Ector. 2013. "Pseudostaurosira cataractarum comb. nov. (Bacillariophyta): type analysis, ecology and world distribution of a former "centric" diatom." Acta Nova 6 (1-2): 53-63.

Williams, D. M. 1986. "Comparative morphology of some species of Synedra Ehrenb. with a new definition of the genus." Diatom Research 1 (1): 131-152. doi: 10.1080/0269249X.1986.9704963

Williams, D. M., and F. E. Round. 1987. "Revision of the genus Fragilaria. Diatom Research 2 (2): 267-288." doi: 10.1080/0269249X.1986.9704976

Witkowski, A., and H. Lange-Bertalot. 1993. "Established and new diatom taxa related to Fragilaria schulzii Brockmann." Limnologica 23 (1): 59-70. 


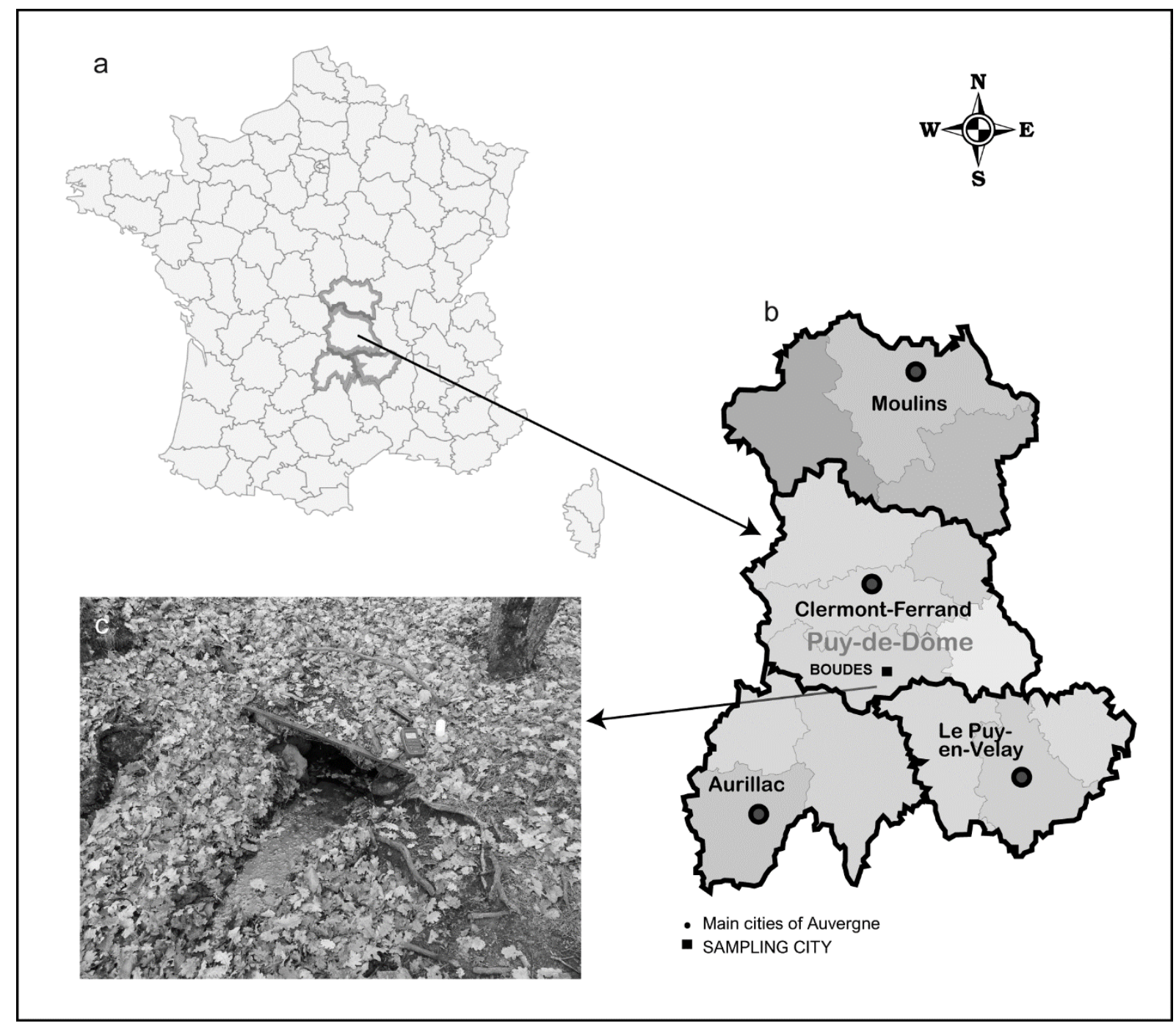

Figure 1. Map of the studied springs. a: map of Europe; $b$ and c: general location map of the French Massif Central and of the study area where Bard springs are located (square); $d$ : photography of the Bard 2 spring. 

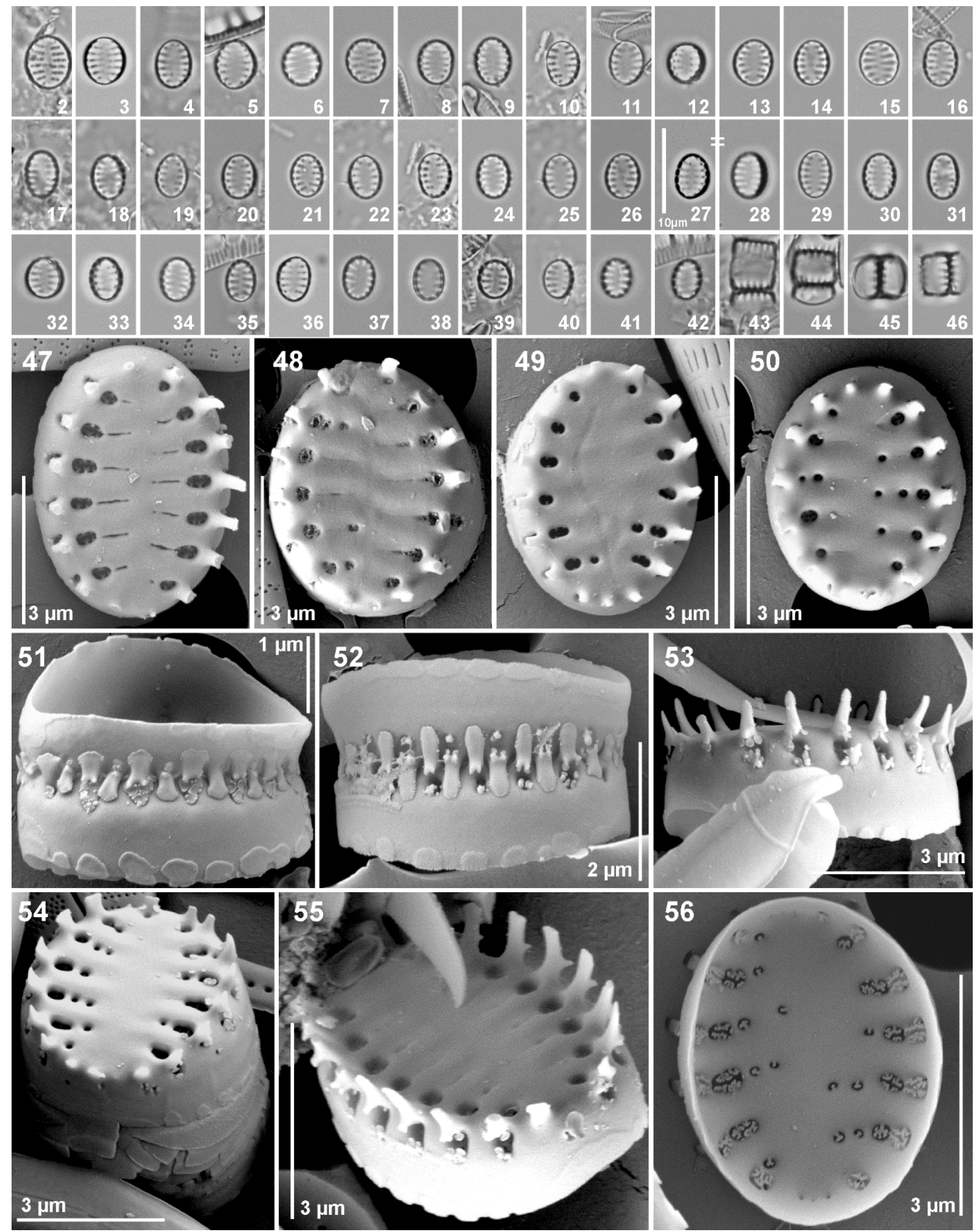

Figures 2-56. Pseudostaurosira bardii Beauger, C.E. Wetzel et Ector sp. nov. LM (Figures 2-46). Type population from Bard 2 spring. Figures 43-46 show a short chain with frustules in girdle view. SEM (Figures 47-56). Type population from Bard 2 spring. (47-50) Overall characteristics of the outer surface of the valve face. Notice the areola pattern that differs from one photo to the others (no more than three areolae per stria) and the presence of volae. (51-53) Girdle view of a frustule and neighbouring valve still attached $(51,52)$. Notice the siliceous plaques present along valve mantle edge and interlocking spines with developing ligulae. (54) Tilted valve showing the opened girdle bands. (55) Tilted valve showing characteristics of the external valve surface and the valve mantle. Notice the position of spines and pore fields weakly developed. (56) Inner view of valve. Inner opening 
of the areolae present also finely branched closing plates. Scale bars $10 \mu \mathrm{m}$ (Figures 2-46); $3 \mu \mathrm{m}$ (Figures 47-50, 53-56); $2 \mu \mathrm{m}$ (Figure 52); $1 \mu \mathrm{m}$ (Figure 51).

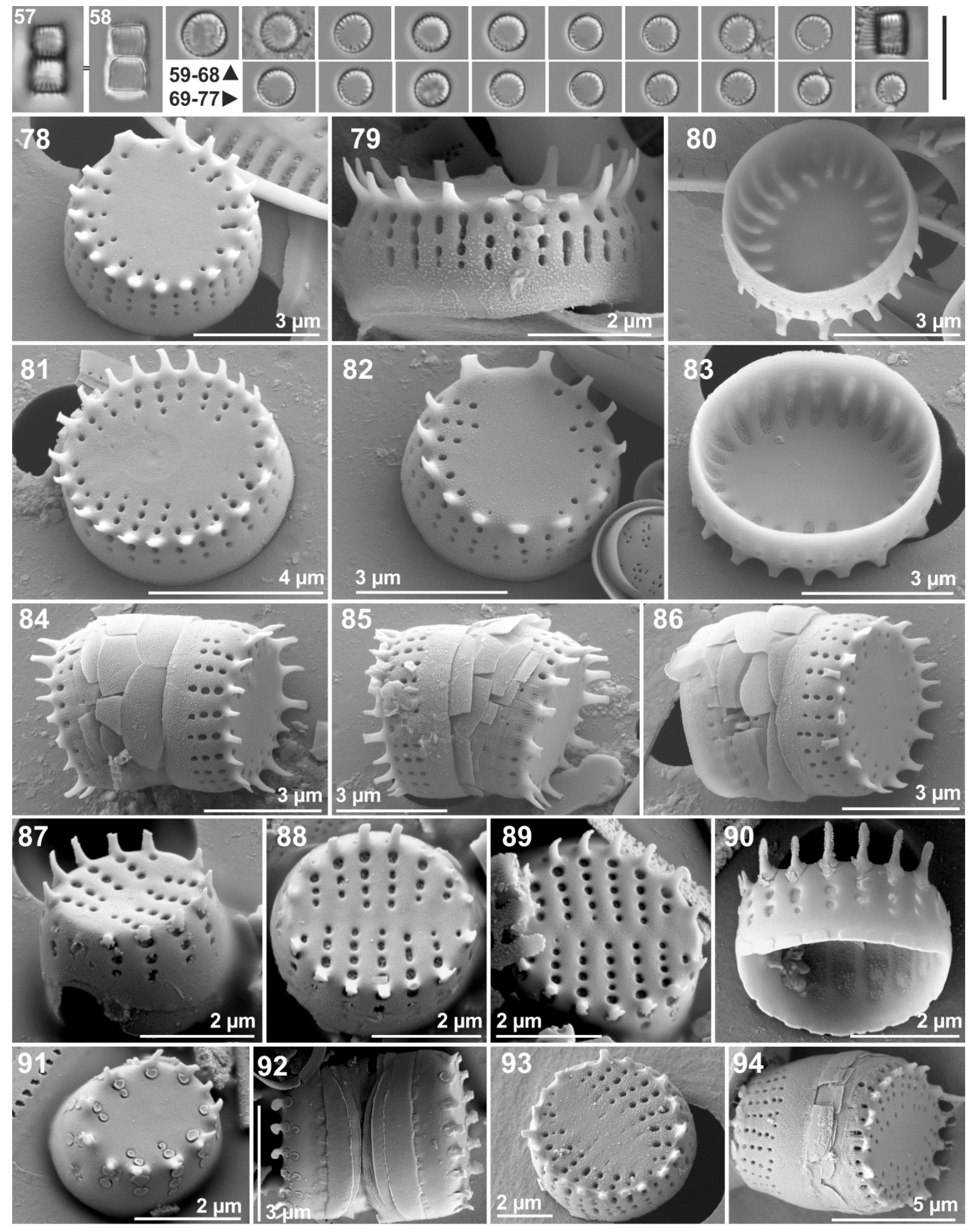

Figures 57-94. Similar small araphid species in LM and SEM. Figures 57-86. Population of Pseudostaurosira cataractarum observed in two springs of the French Massif Central (Puits and Zagat springs). Figures 87-94. SEM type materials of similar small elliptic 'araphid' species. Figures 87-90. P. trainorii E. Morales (Avery Pond, Connecticut USA); Figures 91, 92. Pseudostaurosiropsis connecticutensis E. Morales (Avery Pond, Connecticut USA); Figures 93, 94: Pseudostaurosira 
cataractarum (Hustedt) C.E. Wetzel, E. Morales et Ector (Java, Indonesia). Scale bars $10 \mu \mathrm{m}$ (Figures 57-77); $5 \mu \mathrm{m}$ (Figure 94); 4 m (Figure 81); $3 \mu \mathrm{m}$ (Figures 78, 80, 82-86, 92); $2 \mu \mathrm{m}$ (Figures 79, 87$91,93)$.

Table 1: Physical and chemical variables measured in the Bard 2 spring at Boudes on December 11, 2015.

\begin{tabular}{lr}
\hline Conductivity $\left(\mu \mathrm{S} \mathrm{cm}^{-1}\right)$ & 6350 \\
$\mathrm{pH}$ (pH units) & 6.57 \\
Temperature $\left({ }^{\circ} \mathrm{C}\right)$ & 15.1 \\
Oxygen (\%) & 0.34 \\
$\mathrm{Li}^{+}\left(\mathrm{mg} \mathrm{L}^{-1}\right)$ & 4.80 \\
$\mathrm{Na}^{+}\left(\mathrm{m} \mathrm{L}^{-1}\right)$ & 911.15 \\
$\mathrm{NH}_{4}^{+}\left(\mathrm{mg} \mathrm{L}^{-1}\right)$ & 1.35 \\
$\mathrm{~K}^{+}\left(\mathrm{mg} \mathrm{L}^{-1}\right)$ & 200.72 \\
$\mathrm{Mg}^{2+}\left(\mathrm{mg} \mathrm{L}^{-1}\right)$ & 135.46 \\
$\mathrm{Ca}^{2+}\left(\mathrm{mg} \mathrm{L}^{-1}\right)$ & 229.36 \\
$\mathrm{~F}^{-}\left(\mathrm{mg} \mathrm{L}^{-1}\right)$ & 1.24 \\
$\mathrm{Cl}^{-}\left(\mathrm{mg} \mathrm{L}^{-1}\right)$ & 782.80 \\
$\mathrm{NO}_{3}^{-}\left(\mathrm{mg} \mathrm{L}^{-1}\right)$ & 0.13 \\
$\mathrm{NO}_{2}^{-}\left(\mathrm{mg} \mathrm{L}^{-1}\right)$ & $<0.05$ \\
$\mathrm{PO}_{4}^{3-}\left(\mathrm{mg} \mathrm{L}^{-1}\right)$ & 0.08 \\
$\mathrm{HCO}^{3-}\left(\mathrm{mg} \mathrm{L}^{-1}\right)$ & 2475.00 \\
$\mathrm{SO}_{4}^{2-}\left(\mathrm{mg} \mathrm{L}^{-1}\right)$ & 37.77 \\
\hline
\end{tabular}

Table 2: Physical and chemical variables measured in the Puits and Zagat springs on December 28, 2016 and January 30, 2017 respectively.

\begin{tabular}{lrr}
\multicolumn{2}{c}{ Puits spring } & \multicolumn{2}{c}{ Zagat spring } \\
\hline Conductivity $\left(\mu \mathrm{S} \mathrm{cm}^{-1}\right)$ & 1464 & 4960 \\
$\mathrm{pH}(\mathrm{pH}$ units) & 7.06 & 6.71 \\
Temperature $\left.{ }^{\circ} \mathrm{C}\right)$ & 8.1 & 8.9 \\
Oxygen (\%) & 33.6 & 10.3 \\
$\mathrm{Li}^{+}\left(\mathrm{mg} \mathrm{L}^{-1}\right)$ & 5.99 & 1.51 \\
$\mathrm{Na}^{+}\left(\mathrm{m} \mathrm{L}^{-1}\right)$ & 920.82 & 227.33 \\
$\mathrm{NH}_{4}^{+}\left(\mathrm{mg} \mathrm{L}^{-1}\right)$ & 0.75 & 0.54 \\
$\mathrm{~K}^{+}\left(\mathrm{mg} \mathrm{L}^{-1}\right)$ & 112.61 & 41.79 \\
$\mathrm{Mg}^{2+}\left(\mathrm{m} \mathrm{L}^{-1}\right)$ & 82.23 & 48.45 \\
$\mathrm{Ca}^{2+}\left(\mathrm{mg} \mathrm{L}^{-1}\right)$ & 79.33 & 89.91 \\
$\mathrm{~F}^{-}\left(\mathrm{mg} \mathrm{L}^{-1}\right)$ & 0.90 & 0.41 \\
$\mathrm{Cl}^{-}\left(\mathrm{mg} \mathrm{L}^{-1}\right)$ & 419.38 & 39.51 \\
$\mathrm{NO}_{3}^{-}\left(\mathrm{mg} \mathrm{L}^{-1}\right)$ & 0.62 & 0.45 \\
$\mathrm{NO}_{2}^{-}\left(\mathrm{mg} \mathrm{L}^{-1}\right)$ & 0.01 & 0.01 \\
$\mathrm{PO}_{4}^{3-}\left(\mathrm{mg} \mathrm{L}^{-1}\right)$ & 0.08 & 0.08 \\
$\mathrm{HCO}^{3-}\left(\mathrm{mg} \mathrm{L}^{-1}\right)$ & 920 & 2570 \\
$\mathrm{SO}_{4}^{2-}\left(\mathrm{mg} \mathrm{L}^{-1}\right)$ & 59.93 & 39.70 \\
\hline
\end{tabular}


Table 3.Comparison of morphological characteristics of taxa similar to Pseudostaurosira bardii sp. nov. based on the reexamination of the material types.

\begin{tabular}{|c|c|c|c|c|c|}
\hline Species & $\begin{array}{l}\text { Valve length } \\
\text { and width } \\
(\mu \mathrm{m})\end{array}$ & $\begin{array}{l}\text { Striae density (in } 10 \mu \mathrm{m} \text { ) } \\
\text { and morphology }\end{array}$ & $\begin{array}{l}\text { Valve shape; } \\
\text { sternum }\end{array}$ & Girdle bands & Closing plates \\
\hline $\begin{array}{l}\text { Pseudostaurosira } \\
\text { bardii sp. nov. }\end{array}$ & $\begin{array}{l}4.0-6.5 \\
3.0-5.5\end{array}$ & $\begin{array}{l}12-16 \text {; uniseriate, } \\
\text { composed of } 1-2(3) \\
\text { areolae, round to elliptical }\end{array}$ & $\begin{array}{l}\text { elliptical to } \\
\text { rounded; } \\
\text { generally wide }\end{array}$ & $\begin{array}{l}\text { open, segmented } \\
\text { (quasifract), not } \\
\text { perforated }\end{array}$ & $\begin{array}{c}\text { volae robust, } \\
\text { arising from the } \\
\text { inner periphery of } \\
\text { each areola }\end{array}$ \\
\hline $\begin{array}{l}\text { Pseudostaurosira } \\
\text { cataractarum } \\
\text { (Hustedt) C.E. } \\
\text { Wetzel, E. Morales } \\
\text { et Ector }\end{array}$ & $\begin{array}{l}5.8-8.2 \\
5.4-7.2\end{array}$ & $\begin{array}{l}\text { 15-18; uniseriate, } \\
\text { composed of round to oval } \\
\text { areolae decreasing in size } \\
\text { from the valve face/mantle } \\
\text { edge to both the central } \\
\text { sternum and the valve } \\
\text { mantle }\end{array}$ & $\begin{array}{l}\text { round to slightly } \\
\text { elliptical; broad }\end{array}$ & $\begin{array}{l}\text { open, segmented } \\
\text { (quasifract) and } \\
\text { not perforated }\end{array}$ & not observed \\
\hline $\begin{array}{c}\text { Pseudostaurosira } \\
\text { trainorii } \\
\text { E. Morales }\end{array}$ & $\begin{array}{l}1.9-8.6 \\
1.7-4.4\end{array}$ & $\begin{array}{l}20-25 \text {; uniseriate, } \\
\text { composed of mainly } 1 \text { to } 6 \\
\text { round or slightly } \\
\text { rectanqular areolae }\end{array}$ & $\begin{array}{l}\text { elliptical to } \\
\text { rounded; } \\
\text { generally wide }\end{array}$ & open & $\begin{array}{l}\text { volae finely } \\
\text { branched closing } \\
\text { plates }\end{array}$ \\
\hline $\begin{array}{l}\text { Pseudostaurosirops } \\
\text { is connecticutensis } \\
\mathrm{E} \text {. Morales }\end{array}$ & $\begin{array}{l}1.9-13.5 \\
1.5-4.7\end{array}$ & $\begin{array}{c}\text { (12)17-20(28); uniseriate, } \\
\text { composed of mainly } 1 \text { to } 3 \\
\text { round or slightly elliptical } \\
\text { areolae }\end{array}$ & $\begin{array}{l}\text { round to } \\
\text { narrowly } \\
\text { elliptical; wide, } \\
\text { but narrower as } \\
\text { the number of } \\
\text { areolae on the } \\
\text { valve face } \\
\text { increases }\end{array}$ & $\begin{array}{l}\text { open, not } \\
\text { segmented }\end{array}$ & $\begin{array}{l}\text { circular, flattened, } \\
\text { plate-like } \\
\text { structures almost } \\
\text { entirely occluding } \\
\text { the areolar } \\
\text { opening }\end{array}$ \\
\hline
\end{tabular}

